Article

\title{
How Sub-Saharan African Countries Students Choose Where to Study Abroad: The Case of Benin
}

\author{
Gildas Kadoukpè Magbondé \\ Faculty of Economics and Management, Gaston Berger University, Saint-Louis, Senegal; \\ E-Mail: gildasmagbonde@gmail.com
}

Submitted: 13 September 2020 | Accepted: 3 December 2020 | Published: 25 March 2021

\begin{abstract}
This article provides new evidence on how students choose a country of destination to conduct their academic studies. Based on a multinomial logistic model, it examines the contribution of the quality of education, institutions and the host country's economic factors to the choice of the destination country. The results indicate that quality education and institutions in the host country are the reasons why students show preference for Western countries-North America and the EU. On the other hand, China is chosen as a destination country for its quality of education-compared to Benin-and not because of its institutional infrastructure. Furthermore, the results do not confirm the hypothesis that African student migration is poverty-driven, as economic factors do not affect the choice of any destination country.
\end{abstract}

\section{Keywords}

academic life; Benin; China; economic opportunities; education; European Union; migrations; North America

\section{Issue}

This article is part of the issue "Decision-Making under Uncertainty: African Migrants in the Spotlight" edited by Didier Ruedin (University of the Witwatersrand, South Africa / University of Neuchâtel, Switzerland).

(C) 2021 by the author; licensee Cogitatio (Lisbon, Portugal). This article is licensed under a Creative Commons Attribution 4.0 International License (CC BY).

\section{Introduction}

The last three decades have witnessed a steady growth in international migrant flows. Between 1995 and 2019, they have grown by $56 \%$ and recently, they are estimated to be about $3.5 \%$ of the world's population (International Organization for Migration, 2020). Economic factors such as unemployment, poverty (Mayda, 2010; Migali \& Scipioni, 2018; Neumann \& Hermans, 2017) and noneconomic factors such as political instability and human rights abuses (Hatton, 2016) are identified as the driving forces behind migrants' movement. International students, a subset of international migrants, have also grown in number. Between 1998 and 2017, international student flows increased from 2 million to 5,3 million (OECD, 2019); African students in countries other than theirs are also growing in number (Efionayi \& Piguet, 2014; Terrier, 2009).

The choice of the host country is critical to migrants. Doherty and Evershed (2018) pointed out that inter- national student flows to the UK and Australia have increased recently. However, only a few African migrants migrate to these countries; instead, the majority of potential African migrants have expressed their willingness to migrate to Western countries and other African countries (Sanny, Logan, \& Gyimah-Boadi, 2019). Regarding African students, most of them are willing to study in Europe and North America (Efionayi \& Piguet, 2014). China is also an attractive destination to international students due to its recent rapid economic transformation (Cui, 2006).

To explain why international students choose a particular destination for their studies, Abbott and Silles (2016) identified the host country's quality of education as a critical factor. Students from developing countries nourish the ambition to be educated in developed countries where highly ranked universities provide world-class education. Their goal remains to quench their thirst for knowledge and increase their expected future income (Abbott \& Silles, 2016; Basford \& Riemsdijk, 2017; Beine, 
Delogu, \& Ragot, 2018; Beine, Noël, \& Ragot, 2014; Cui, 2006; Van Bouwel, 2010). The availability of educational facilities (Beine et al., 2014, 2018) and scholarships (Basford \& Riemsdijk, 2017) are motivating factors. Contrariwise, the lack of educational facilities in their home country is a pushing factor that further encourages them to improve their human capital in developed countries (Rosenzweig, 2006). Moreover, with highly globalised higher education, developed countries attract the best brains from developing countries as sources of scientific productivity (Gaulé \& Piacentini, 2013).

Institutional factors play a role in the decision to migrate and the choice of the destination country (Bergh, Mirkina, \& Nilsson, 2015; Docquier, Rapoport, \& Salomone, 2012), as they determine transaction costs, the level of certainty and motivation. Students are thus more likely to study in countries that are less corrupt (Poprawe, 2015), have a similar religious affiliation (Connor, 2012) and colonial ties (Didisse, Nguyen-Huu, \& Tran, 2018) to their countries of origin. Students from democratic countries are more likely to study in democratic countries as they value democratic freedom. In this regard, Didisse et al. (2018) showed that the freedom to leave and internal conflict predict the student migration.

Although there is an extensive literature concerning international student migration (Abbott \& Silles, 2016; Basford \& Riemsdijk, 2017; Cui, 2006; Docquier et al., 2012; Efionayi \& Piguet, 2014; Terrier, 2009; Tilly, 2007; Zhang \& Zhang, 2014; Zhao, Yuan, \& Wei, 2019), the contribution of institutions in the choice of the destination country has been overlooked. No evidence exists on the effect of differentials in education capacities and institutions in a comparative setting. While the international allocation of western students has been extensively explored within the global economy of knowledge, only a handful of empirical studies have been concerned with African students (Efionayi \& Piguet, 2014; Zhang \& Zhang, 2014), particularly with Beninese students.

Benin is a perfect ground on which the link between institutions and education and student migrants may provide new insights. Firstly, Benin's education system performance depends on political institutions; political instability and the dictatorial regime from 1960 to 1990 weakened the education system. As this would have reduced future incomes, students may have opted for migration (Bertocchi \& Strozzi, 2008). Secondly, the high unemployment rate due to the poor performance of the education system (Dakpo, Yarou, \& Flénon, 2011) forces Beninese students to study abroad to increase their international competitiveness. Third, the majority of Beninese students study in Europe because of colonial ties with France or in the USA for their institutional similarity to France.

More concerned with the intention to migrate than the actual migration, this article has assessed factors that motivate Beninese students' choice of destination countries. Specifically, it has analysed the role played by institution and education differentials between Benin and preferred destination countries and reexamined the contribution of economic factors. Taking into account the role of institutions and education, the determinants of the choice of the destination country are heterogeneous and vary with the country of destination. The main findings show that, regardless of the preferred destination, the quality of education is crucial. On the other hand, in addition to the quality of education, the choice to study in Western countries is influenced by their democratic institutions. These findings have strong implications for development policy. Policymakers in the Global South ought to invest in their educational system to make it more efficient and to implement institutional reforms.

\section{A Review of the Literature}

\subsection{Concepts and Theories}

International students are seen either through a 'mobility' lens or a 'migration' lens (King \& Raghuram, 2013). Through a migration lens, they are portrayed as a subset of international migrants. For the United Nations (2012, p. 2), an international migrant is any person or individual that leaves his or her country of origin for a minimum period of one year (the long-term migrant) or three months (the short-term migrant) for any kind of motive. The International Organization for Migration (2003, p. 9) defines international migration as "the movement of a person or a group of persons across an international border."

Two theoretical strands, namely the supply-side and the demand-side, have enlightened international student migration. The first one states that the forces that structure student migration are on the side of the students. It privileges demand for overseas education. The supply-side theory argues that international student flows are shaped by immigration policies in the destination countries, the financial interests of those who organise, supply, and market elite higher education opportunities (Findlay, 2011). This theory also concedes that international students are attracted for their talents (Waters, 2006) and their cultural capital (Findlay, 2011), highly valued in the destination countries.

\subsection{Education, Economic and Other Non-Economic Determinants}

Though migration and intention to migrate are understood as two different concepts, they are driven by the same factors (Efionayi \& Piguet, 2014; Lu, 1999). In this respect, the determinants of migration presented in this section are treated as determinants of intention to migrate. These factors are classified into two broad categories, namely pulling and pushing determinants (Lee, 1966).

Unemployment, poverty and lack of employment opportunities have been identified as economic pushing factors (Population Council, 2016) while economic 
development and the availability of jobs in destination countries are economic pulling factors. Being unemployed fuels the desire to migrate (Migali \& Scipioni, 2018). Young migrants from developing countries are on the move for better jobs (International Labour Office, 2016). Mayda (2010) reported in a study that economic growth in destination countries is correlated with increased migrant flows. Non-economic factors include institutional, educational and social factors. For example, in fragile states where political instability affects people's daily lives, people migrate in search of a better life. Cultural proximity (Lanati \& Venturini, 2018) and linguistic similarities (Lanau, 2019) affect the direction of migration flows; colonial ties between countries of origin and destination reduce institutional differences and make life easier for migrants in their countries of destination. Browne (2017) has shown that migration is educationdriven. Giulietti, Wahba, and Zenou (2018) and Docquier, Tansel, and Turati (2020) highlighted the role of social capital; the network abroad (friends and family) facilitates access to information, financial support and assistance in finding jobs (Munshi \& Rosenzweig, 2016).

As student migration is subsumed in international migration (Findlay, 2011), both share the same determinants. Economic factors such as development deferential between countries of origin and destination (Abbott \& Silles, 2016) and economic growth in the country of destination (Cui, 2006) are instrumental in attracting international students. Regarding non-economic determinants, the focus is laid on cultural (Zhao et al., 2019), socioeconomic (Abbott \& Silles, 2016; Migali \& Scipioni, 2018) and political factors (Plopeanu et al., 2018). Furthermore, social networks (Efionayi \& Piguet, 2014), migration experiences (Migali \& Scipioni, 2018) and family support (Efionayi \& Piguet, 2014; Palloni, Massey, Ceballos, Espinosa, \& Spittel, 2001) count for international student migration.

One of the most important decisions regarding study migration is the choice of the study country. In light of the literature review, factors that affect the decision to migrate matter when choosing the destination country. A recent study by Basford and Riemsdijk (2017) concluded that students' perceptions of the quality of education and the availability of scholarships affect their choice of the destination country. For Efionayi and Piguet (2014), African students choose to study in Europe because of the quality of education and the availability of educational facilities. The choice of Chinese universities by international students has been explained by the availability of scholarships (Zhang \& Zhang, 2014), the quality of education (Lu, Li, \& Chen, 2019), China's rapid economic growth and the low cost of education compared to Western countries (Cui, 2006) and the development gap between China and other developing countries (Yue, 2013). The following hypotheses were formulated:

H1: Students pick a country if its quality of education is greater compared to their home countries.
$\mathrm{H} 2$ : The more a country is economically developed, the more it attracts students.

\subsection{The Role of Institutional Determinants}

5 Playing a pivotal role in the choice of the destination country, institutions matter for student migration. Through three strands, institutions have been linked to migration. The first strand deals with the effect of the home and host country's institutions on migrant flows (Ariu, Docquier, \& Squicciarini, 2016; Bertocchi \& Strozzi, 2008; Connor, 2012; Docquier et al., 2012; Poprawe, 2015; Tilly, 2007). The second strand is more concerned with the effect of migration on the home countries' institutions (Docquier, Lodigiani, Rapoport, \& Schiff, 2016; Li, McHale, \& Zhou, 2016). For the third, migrants can affect host countries' institutions through voicing and voting (Hirschman, 1970). The fashion in which this article links institution to migration, falls in the first strand. What are thus institutions? Which role do they play? How are they related to migration regarding the first strand?

Defined either as a set of rules that govern interactions in society (North, 1991) or as rules of the game (Coase, 1937), institutions contribute to the reduction of uncertainty and transaction costs and provide incentives (North, 1991; Vaal \& Ebben, 2009). Classified in two broad categories, institutions can be informal-taboos, customs, traditions, and codes of conduct or formal-constitutions, laws and property rights. Regardless of their nature, the fundamental role of institutions is to reduce uncertainties, both environmental and behavioural. The first is related to the alteration of the conditions that define exchange and the second pertains to opportunistic behaviour including the purposeful disguise and distortion of information (Sen, Te Velde, Wiggins, \& Cali, 2006). Mo (2001) argues that corruption, at a certain level, generates sociopolitical instability in the sense that it creates uncertainty and reduces productivity.

Empirical studies on migration-institution nexus (Ariu et al., 2016; Bertocchi \& Strozzi, 2008; Connor, 2012; Docquier et al., 2012; Poprawe, 2015; Tilly, 2007) reported that skilled migrants are interested in the host country's institutions. The guarantee of economic freedom in the host country attracts migrants, resulting in their departure from the country of origin. Ariu et al. (2016) reported that highly skilled university students migrate to countries with adequate institutions, while host-country institutions do not attract low-skilled university students. The authors justified the weak interest of unskilled students in the destination country's institutions by their limited access to information on foreign institutions. A study by Bergh et al. (2015) assessed the effect of global governance indicators on the decision to migrate using a gravity model; the results show that migrants choose to migrate to countries with sound democratic institutions. Labour market institutions are integral to migration flows; Migali (2018) showed that 
an increase in the host countries' trade union density is associated with lower flows in migration. Informal institutions such as interpersonal trust (Tilly, 2007), corruption (Poprawe, 2015) and religious institutions (Connor, 2012) are also germane to migration decision:

H3: Students pick a country if its institutional infrastructures are better compared to their home countries.

\section{Data and Methods}

\subsection{Data Collection}

In this study conducted in Benin, two universities were randomly selected: the University of Abomey-Calavi, which is the largest public university in Benin, and the Haute Ecole de Commerce et de Management (School of Business and Management), which is a private institution. On a random basis, a sample of 414 students was drawn from a list of students obtained from the students' associations. These students were surveyed between January and February 2020. A questionnaire written in French was digitised using KoBoCollect for data collection. After a pre-test, the questionnaire was considerably improved. Data was collected on the socioeconomic characteristics of students, their perceptions on the institutions and the quality of education in Benin and their preferred countries of destination using a 7-point Likert scale ranging from 1 (strongly disagree) to 7 (strongly agree). Data was also collected on culture, economic factors in the preferred host country. Table 1 (in Supplementary File 1) presents the variables and their metrics.

\subsection{Methods}

The empirical model employed in this article is derived from a simple theoretical model developed by Bertocchi and Strozzi (2008) in which the migration decision is explained by wage and institutions differential. The explicit model is given by the following equation:

$$
d_{t}=\left(W_{t}^{d}-W_{t}^{b}\right)+\delta\left(l_{t}^{d}-l_{t}^{b}\right)-c
$$

The decision to migrate $\left(d_{t}\right)$ is a function of the wage differential $\left(W_{t}^{d}-W_{t}^{b}\right)$, between the country of destination (d) and the home country (b), the institution differential $\left(l_{t}^{d}-l_{t}^{b}\right)$ and the cost of migration (c). $t$ stands for time and $\delta$ is the weight of the gap in institutions (institution differential). As we are working on cross-sectional data, the subscript $t$ is replaced by $i$. An individual decides to migrate when the gains of migration are superior to the costs incurred.

As migration decision is conditional on the destination and the send countries' characteristics, we model the choice of the destination country as a function of the student's socioeconomics characteristics $\left(P_{i}\right)$, the discrimination variable $\left(D^{d}\right)$, the cultural proximity between the host country and Benin $\left(\mathrm{Cul}_{i}\right)$, the economic condi- tion in the destination country $\left(E^{d}{ }_{i}\right)$, the institution differential $\left(I_{i}^{d}-I_{i}^{b}\right)$ and the gap in education or the differential in education quality between Benin and a given preferred chosen destination $\left(E d_{i}^{d}-E d_{i}^{b}\right)$.

This article is not concerned with actual migration; rather, it examines the destination choice within an intent framework. Thus, students were asked-regarding institutions, education quality and economic opportunities in the destination country-what their preferred destination country would be in their intention to migrate for studies. Consequently, the dependent variable is polytomous, taking five values concerning the preferred destination countries (or regions)-North America, EU, China, African countries and other destinations. That fits a multinomial logistic model. Taking African countries as a reference, the probability that a student chooses a destination country among the four other destinations has been estimated. The mathematical expression of the fitted multinomial logistic model is as followed:

$$
P_{i}=P_{r}(D=i)=\left\{\begin{array}{l}
\frac{1}{1+\sum_{m=2}^{k} \exp (Z)} \text { if } i=1 \\
\frac{\exp (Z)}{1+\sum_{m=2}^{k} \exp (Z)} \text { if } i>1
\end{array}\right.
$$

with $Z=X_{j} \lambda_{m} i=1,2, \ldots 5$

$P_{i}$ stands for the probability that a student preferred a country $i, D$ for the destination country, $\lambda_{m}$ represents the vectors of the parameters to be estimated and $X_{j}$ the vector of the explanatory variables.

The explicit form of $Z$ is:

$$
\begin{aligned}
Z & =\lambda_{0}+\lambda_{1} P_{i}+\lambda_{2} D^{d}{ }_{i}+\lambda_{3} \mathrm{Cul}_{i}+\lambda_{4} E^{d}{ }_{i}+ \\
& +\lambda_{5}\left(E d_{i}^{d}-E d_{i}^{b}\right)+\lambda_{6}\left(I^{d}{ }_{i}-I^{b}{ }_{i}\right)
\end{aligned}
$$

The variables that measure the level of discrimination in the host country $\left(D^{d}\right)$, the cultural proximity between the host country and Benin $\left(\mathrm{Cul}_{i}\right)$, the economic factors in the destination country $\left(E^{d}{ }_{i}\right)$ are respectively proxied by the index of discrimination in the preferred destination country, the index of cultural proximity and index of the host country's economic factors. Furthermore, we have computed the index of education quality for Benin and the preferred destination country and have taken their difference as the proxy for the institutions differential or the gap in the quality of institutions $\left(I^{d}{ }_{i}-I_{i}^{b}\right)$. The same computation was also performed to calculate the gap in the quality of education $\left(E d_{i}^{d}-E d_{i}^{b}\right)$.

These indices are calculated by Principal Component Analysis, a statistical method that aggregates the collinear individual variable to obtain a composite index that captures as much information as possible from the individual variables. Since the idea is to account for the highest possible variation in the set of individual variables, using very few factors, the indices calculated are no longer a function of the dimensions of the data on the individual variables but rather of the statistical 
dimensions of the data. To illustrate that approach, the results concerning the calculation of the index of the quality of education and institutions are reported in Tables 7 to 14 in Supplementary File 2.

In the empirical model, indices measuring discrimination and cultural proximity, the characteristics of the respondents $\left(P_{i}\right)$, including age, gender, the type of university attended, the student and father's level of education are control variables. The expected signs and descriptive statistics of all the variables in the empirical model are presented respectively in tables 2 and 3 in Supplementary File 1.

\section{Empirical Results}

\subsection{Socioeconomic Characteristics of the Respondents}

The socioeconomic characteristics of the respondents are presented in Table 4 of the Supplementary File 1. The surveyed students are 15 to 34 years old with an average of $23.8 .69 \%$ are 20 to 24 years old, $11 \%$ are 15 to 19 years old, $51 \%$ are 20 to 24 years old and $38 \%$ are between 24 and 34 years old. The majority of respondents are Catholic (57\%), male (69\%), enrolled in a public university (83\%), and studying economics, law and political science and humanities. In terms of their level of study, $38 \%$ are sophomore, $14 \%$ are in a bachelor's year and $27 \%$ are enrolled in a master or doctoral programme. As for foreign languages, although all speak French and 35\% understand English, only 4\% understand German and Chinese, while 6\% understand Spanish. Concerning the level of education, $80 \%$ of their parents (fathers) are educated compared to $20 \%$ uneducated.

\subsection{Choice of Destination Countries}

The distribution of respondents by preferred country of destination is depicted in Figure 1. It appears that the majority of the surveyed students have expressed their willingness to study outside Africa, particularly in Western countries. $43 \%$ of the respondents would like to study in North America and 39\% in EU countries whereas only $6 \%$ and $7 \%$ of them would like to study respectively in China and other African countries. Respondents' preference for studying outside the African continent, notably for Western universities, could be explained by how easily they can find a job and even embrace a university career with a degree earned in Western universities (Efionayi \& Piguet, 2014). Overall, the symbolic prestige attached to degrees obtained abroad and the resulting ease of social mobility explain the preference for studying in Western countries (Waters, 2006). Efionayi and Piguet (2014) explained the enthusiasm of African students for North America by the quality of education. Another reason that may well explain the preference for North America is the quality of its institutions. For instance, Canada is known and often cited for its democratic calmness and peaceful land; furthermore, the USA is described as a land of democracy. These countries' soothing study conditions, due to their institutions, would explain the preference for them.

\subsection{Perceived Quality of Education and Institutions in Benin and Host Countries}

After choosing the destination country, respondents were asked to justify the extent to which the quality of

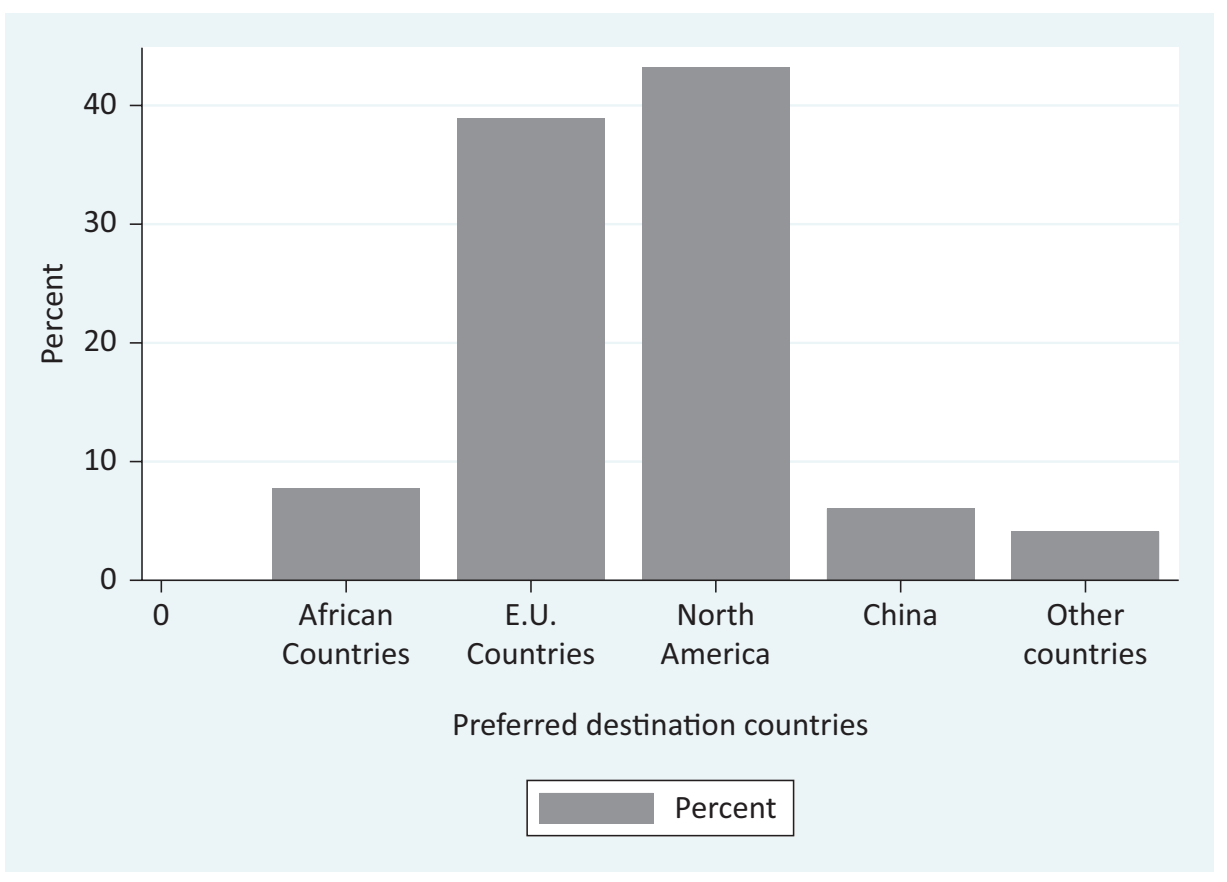

Figure 1. Destinations of choice for students from Benin. 
institutions and education both in the preferred destination region and in their home country Benin contributed to this choice. The aim was to link the choice of their country of destination to the quality of institutions and education system in Benin and the preferred destinations. Figure 2 depicts the average scores of institutions and the quality of the education.

Its analysis reveals that the institutions' average score is lower in Benin than in the destinations. Respondents gave low scores to items that measure the quality of institutions at various levels. They felt that the judiciary is not efficient, property rights are poorly protected, corrupt practices are not at their minimum level and that administrative procedures are sometimes cumbersome. Furthermore, from the respondents' perspective, the institutional state in Benin is a result of democratic freedoms being weakened (Table 5 in Supplementary File 1). Unlike Benin, the average institutional score is higher in the destinations. Countries of the EU and North America have the highest scores, followed by China, other African countries and other possible destination countries. The high level of the Western countries' institutional score is due to their democratic freedoms and efficient judiciary, as the scores attributed to these institutional variables are higher in Western countries than in other destination regions.

The average score for the quality of education shows the same distribution as the average score for the quality of institutions, with some exceptions. Indeed, the average score for the quality of education in Benin is lower than those of destination countries; in this respect, the distribution of the score for the quality of education is similar to that of institutions. Compared to the destination countries, Benin's education system is less efficient, as stated by the respondents. While respondents consider Benin's education system to be moderately efficient, they feel that it does not have sufficient infrastructure (classrooms, libraries, qualified teachers, teaching materials, accessible computers and Internet, etc.) to ensure quality education; nor does it offer sufficient scholarships to students (Figure 2). On the other hand, the distribution of the quality of education score is no longer similar to that of the quality of institutions when looking only at destination countries. China and Western countries have the highest scores, with China leading slightly. From the respondents' perspective, the provision of scholarships to students and the sufficient availability of infrastructure explain the efficiency of the Chinese education system, as well as the low tuition fees at Chinese universities compared to the tuition fees charged by American, English and Canadian universities.

\subsection{Determinants of Preferred Destination Countries}

\subsubsection{Education Quality}

The quality of education is an instrument in the choice of destination country when the intention to migrate is expressed by students. Before deciding on a country of destination for study, a comparison between the home country's quality of education and that of the country of destination is performed. This basic calculation is the basis for the decision regarding the choice of a country of destination. The willingness to quench their thirst for knowledge in universities that provide world-class education explains this calculation. The education gap becomes the yardstick for the choice of the destination. Better quality of education in the destination country acts as an attractive factor, while a lagging education system in the country of origin is a repulsive factor.

The results of the econometric estimates of the multinomial logistic model are reported in Table 6 in Supplementary File 1. Figure 3 presents a graph of the estimated coefficients of three key variables, including the education differential, the institution differential and host country's economic opportunities along with their

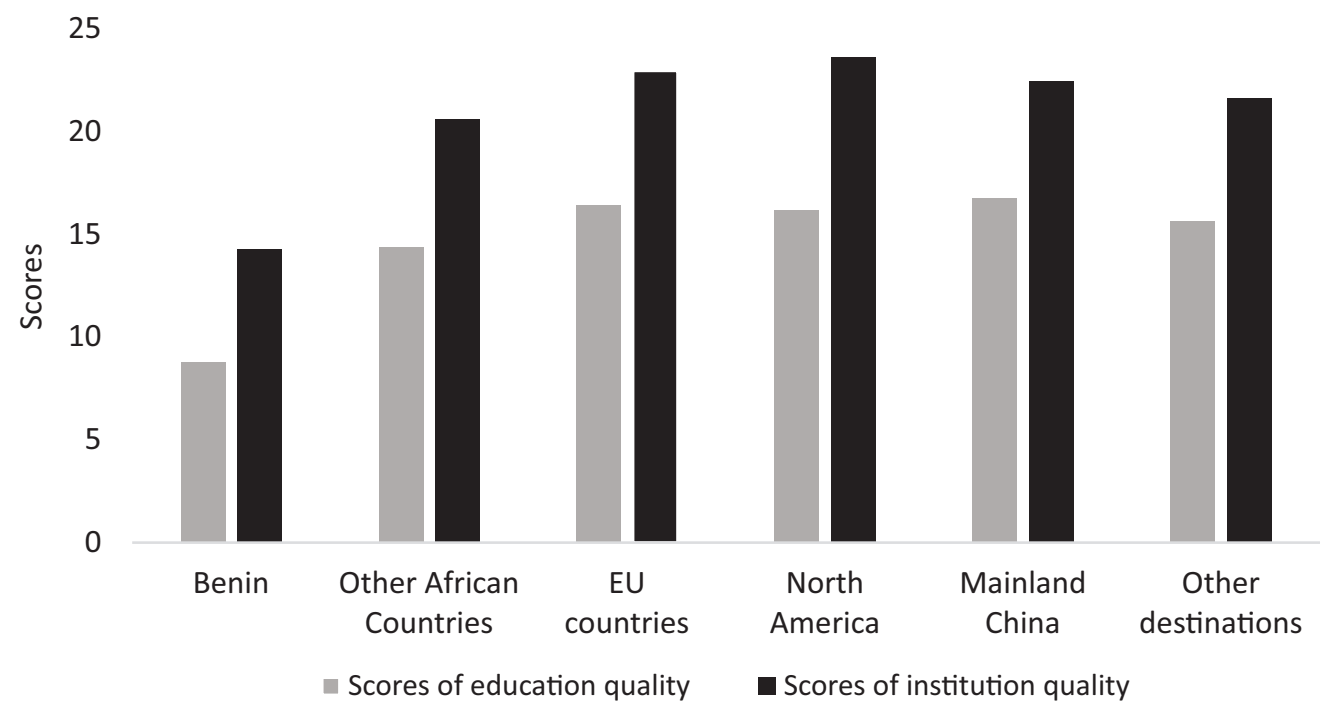

Figure 2. The average scores of institutions and the quality of the education. 


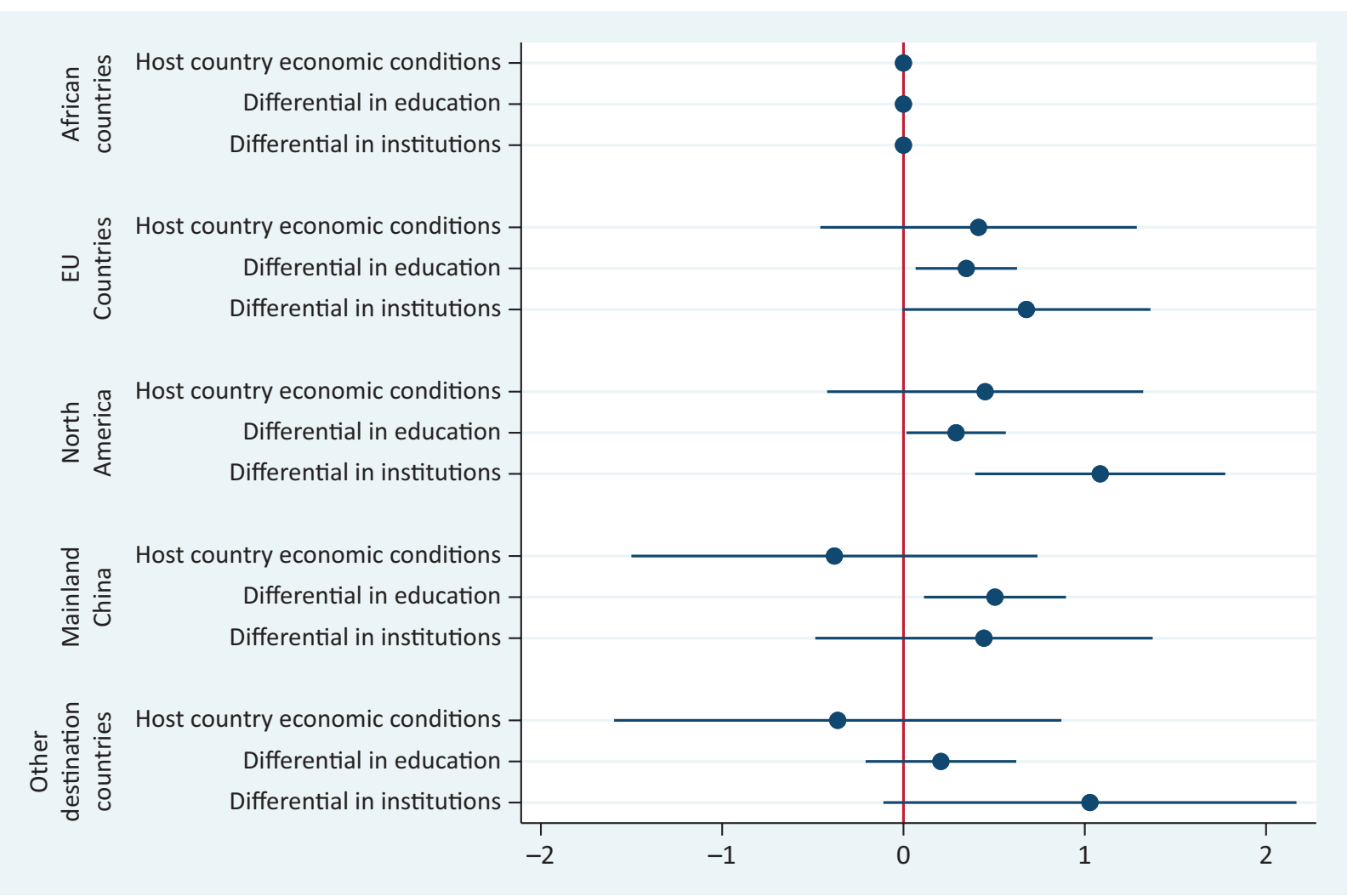

Figure 3. The plot of the multinomial model's point estimates and $95 \%$ confidence intervals. Notes: Figure 3 plots only the coefficients of the explanatory variables of interest regarding the choice of a destination country, including the differential in institutions, the differential in education and the host country's economic opportunities. The control variables are the index of discrimination, cultural proximity and the characteristics of the respondents such as age, gender, the type of university attended, the student and father's level of education (see Table 6 of the Supplementary File 1). The dependant variable is polytomous, taking five possible destinations which are the EU, North America, mainland China, African countries and other possible destinations; African countries are treated as the reference destination (base outcomes). The red reference line at zero indicates which point estimate is significantly different from zero. The data used are collected on a sample of 414 Beninese students in 2020.

confidence interval at $95 \%$. It indicates that the coefficient associated with the education differential is positive and significant at $5 \%$ threshold concerning the choice of EU countries, North America and China, but not significant for the choice of other regions. The education differential is a perfect predictor of the probability that a student decides to study in Western countries and China. Beninese students are attracted by the availability of infrastructure such as libraries, computers and study rooms that guarantee better study conditions, the availability of well-defined curricula, better teachers and researchers, and which allow them to compete in the global labour market.

\subsubsection{Quality of Institutions}

The institutional environment in the destination and origin country is a determining factor regarding the choice of the host country. As studying abroad is understood as a type of investment, the risk related to such a decision is integrated in the calculations, not only to ensure the success of the investment but also to guarantee the profitability of this investment. Lower-quality institutions increase the uncertainties and risks that could impede the success of studies. To this end, it is easier to study in a politically stable, less corrupt country with an efficient and independent judiciary than in a country where institutions deny democratic freedoms and political instability fosters violence of all kinds.

Figure 3 shows that the coefficient related to the institution differential is positive and significant at the $5 \%$ threshold in the choice of EU and North American countries as destination countries. However, it is not the case for China and other destination countries. The probability that a student chooses to study in Western countries rather than an African country is positively related to the institution differential. In their intention to migrate to Western countries for their studies, Beninese students compare the institutions in Benin with those in their destination countries and decide accordingly. The image of America described as a land of freedom and democracy would have contributed greatly to this result. Unlike North American and EU countries, Beninese students do not take into account the differential in the 
quality of institutions between China, other regions and Benin. Although respondents have a favourable opinion of the quality of institutions in these two regions compared to Benin, the choice of China and other destinations as a host country is not motivated by the institutional infrastructure.

\subsubsection{The Host Country's Economic Opportunities}

So far, education differential determines the choice of Western countries and China as a destination country; furthermore, findings show that the gap in institutions does not count in the choice of China as a destination for study. Regarding the host country's economic opportunities, findings in Figure 3 indicate that they do not contribute to the choice of the host country. The coefficient associated with the economic opportunities in the host country is not significant in any destination. Though contrary to our expectations, it does say more about the reasons why African students go to study in developed or emerging countries such as China. It sheds light on the fact that the migration of Beninese students is not driven by the economic conditions in the destination countries. At most, these findings corroborate the role of institutions and the quality of education in the choice of destinations.

Concerning the control variables, the age of the respondents, the type of university attended, the cultural proximity and discrimination in the country of destination are not significant in any of the equations in Table 6 of the Supplementary File 1 . These variables therefore do not contribute to the choice of the destination country for Beninese students. Also, female students and those with highly educated parents are more likely to study in North America. Students with higher levels of education, on the other hand, are less motivated to study in China.

\section{Conclusion}

This article has contributed to the debate on the factors that affect the choice of the destination country for studies abroad. It has focused on the role of institutions and reexamined the effects of the host country's economic opportunities and the institution differential on the choice of a destination. Since skilled migrants contribute to the strengthening of human capital in their destination countries, this article is also a contribution to the debate on the role of institutions in economic development (Acemoglu \& Robinson, 2010). Specifically, the following questions were answered:

Does the difference in the quality of education between the destination and host country affect the choice of the host country? The results show that the quality of education in the preferred destination country is a pulling factor while that of the country of origin is a pushing factor. Beninese students are attracted by the top-notch education quality in Western countries and China and pushed by the relatively low educational standard in Benin. This finding confirms findings of previous studies such as Lu et al. (2019), Yue (2013), Efionayi and Piguet (2014), Zhang and Zhang (2014), Basford and Riemsdijk (2017).

What is the role of institutions in the choice of destination countries? Findings have confirmed their importance; the quality of institutions motivates the choice of Western countries as destinations. The gap in the quality of institutions is an important factor in the choice of the destination country. In this regard, institutions are included in the elementary calculations that lead to the choice of a destination. Thus, countries of the highest institutional standard which reduces uncertainty, even in the presence of limited access to information, are valued. However, this is not the case for China and other regions. The results obtained here are in line with Docquier et al. (2012), Poprawe (2015), and Ariu et al. (2016).

Do students choose a host country based on its economic opportunities? The main findings indicate that the host country's economic factors do not contribute to the choice of a destination. Deciding to study in the EU, North America and China is not conditioned by economic factors. These results contradict previous findings from Cui (2006) and Abbott and Silles (2016) and confirm those of Efionayi and Piguet (2014) that challenge the common belief that African student migration is poverty-driven.

The findings of this survey lead to some policy implications. Policymakers in Benin ought to implement several institutional reforms to limit corruption, improve the efficiency of the judiciary and access to public services. In addition to that, massive public investments must be directed towards educational infrastructures to ensure that students receive a quality education.

\section{Acknowledgments}

This research is funded by the Swiss Sub-Saharan Africa Migration (S-SAM) network, a network that builds and strengthens long-term partnerships between migration researchers from Sub-Saharan Africa and Switzerland.

\section{Conflict of Interests}

The author declares no conflict of interests.

\section{Supplementary Material}

Supplementary material for this article is available online in the format provided by the author (unedited).

\section{References}

Abbott, A., \& Silles, M. (2016). Determinants of international student migration. The World Economy, 39(5), 621-635.

Acemoglu, D., \& Robinson, J. (2010). The role of institutions in growth and development. Review of 
Economics and Institutions, 1(2). http://dx.doi.org/ 10.5202/rei.v1i2.14

Ariu, A., Docquier, F., \& Squicciarini, M. (2016). Governance quality and net migration flows. Regional Science and Urban Economics, 60, 238-248.

Basford, S., \& Riemsdijk, M. (2017). The role of institutions in the student migrant experience: Norway's quota scheme. Population, Space and Place, 23(3), 1-13.

Beine, M., Delogu, M., \& Ragot, L. (2018). The role of fees in foreign education: Evidence from Italy. Journal of Economic Geography, 20(2), 571-600.

Beine, M., Noël, R., \& Ragot, L. (2014). Determinants of the international mobility of students. Economics of Education Review, 41, 40-54.

Bergh, A., Mirkina, I., \& Nilsson, T. (2015). Pushed by poverty or by institutions? Determinants of global migration flows (IFN Working Paper No. 1077). Stockholm: Research Institute of Industrial Economics.

Bertocchi, G., \& Strozzi, C. (2008). International migration and the role of institutions. Public Choice, 137(1), 81-102.

Browne, E. (2017). Evidence on education as a driver for migration. Brighton: Institute of Development Studies.

Coase, R. (1937). The nature of the firm. Economica, 4(16), 386-405.

Connor, P. (2012). International migration and religious selection. Journal for the Scientific Study of Religion, 51(1), 184-194.

Cui, Q. L. (2006). History and reason for foreign students studying in China. Research on Higher Education, 23(2), 4-6.

Dakpo, A., Yarou, I., \& Flénon, A. (2011). L'orientation à l'université: Politique, pratiques et effets sur la dynamique académiques dans les universités publiques du Bénin [Guidance at university: Policy, practice and effects on the academic dynamics in Benin's public universities]. Cotonou: Réseau Ouest et centre africain de recherche en éducation (ROCARE).

Didisse, J., Nguyen-Huu, T., \& Tran, T. (2018). The long walk to knowledge: On the determinants of higher education mobility to Europe. The Journal of Development Studies, 55(6), 1099-1120.

Docquier, F., Lodigiani, E., Rapoport, H., \& Schiff, M. (2016). Emigration and democracy. Journal of Development Economics, 120, 209-223.

Docquier, F., Rapoport, H., \& Salomone, S. (2012). Remittances, migrants' education and immigration policy: Theory and evidence from bilateral data. Regional Science and Urban Economics, 5(12), 817-828.

Docquier, F., Tansel, A., \& Turati, R. (2020). Do emigrants self-select along cultural traits? Evidence from the MENA Countries. International Migration Review, 54(2), 388-422.

Doherty, B., \& Evershed, N. (2018, March 23). The changing shape of Australia's immigration policy. The
Guardian. Retrieved from https://www.theguardian. com/australia-news/2018/mar/24/australias-fierceimmigration-debate-is-about-to-get-louder

Efionayi, D., \& Piguet, E. (2014). Western African student migration: A response to the globalisation of knowledge. International Development Policy, 5, 174-194. https://doi.org/10.4000/poldev.1789

Findlay, A. (2011). An assessment of supply and demandside theorizations of international student mobility. International Migration, 49(2), 162-190.

Gaulé, P., \& Piacentini, M. (2013). Chinese graduate students and US scientific productivity. The Review of Economics and Statistics, 95(2), 698-701.

Giulietti, C., Wahba, J., \& Zenou, Y. (2018). Strong versus weak ties in migration. European Economic Review, 104, 111-137.

Hatton, T. (2016). Refugees, asylum seekers, and policy in OECD countries. American Economic Review, 105(5), 441-445.

Hirschman, A. (1970). Exit, voice, and loyalty: Responses to decline in firms, organizations, and states. Cambridge, MA: Harvard University Press.

International Labour Office. (2016). World employment and social outlook 2016: Trends for youth. Geneva: International Labour Office.

International Organization for Migration. (2003). World migration report 2003. Geneva: International Organization for Migration. Retrieved from https://publications.iom.int/fr/system/files/pdf/ wmr_2003_1.pdf

International Organization for Migration. (2020). World migration report 2020. Geneva: International Organization for Migration.

King, R., \& Raghuram, P. (2013). International student migration: Mapping the field and new research agendas. Population, Space and Place, 19(2), 127-137.

Lanati, M., \& Venturini, D. (2018). Cultural change and the migration choice (IZA DP No. 11415). Bonn: Institute of Labor Economics.

Lanau, G. (2019). Migration drivers: Why do people migrate? EU-Logos Athéna. Retrieved from https://www.eu-logos.org/2019/05/31/migrationdrivers-why-do-people-migrate

Lee, E. S. (1966). A theory of migration. Demography, 3(1), 47-57.

Li, X., McHale, J. M., \& Zhou, X. (2016). Does brain drain lead to institutional gain? The World Economy, 40(7), 1-19. https://doi.org/10.1111/twec.12407

Lu, M. (1999). Do people move when they say they will? Inconsistencies in Individual migration behaviour. Population and Environnement, 20(5), 467-488.

Lu, Z., Li, M., \& Chen, Y. (2019). Destination China: International students in Chengdu. International Migration, 57(3), 356-371.

Mayda, A. M. (2010). International migration: A panel data analysis of the determinants of bilateral flows. Journal of Population Economics, 23(4), 1249-1274.

Migali, S. (2018). Migration and institutions: Evidence 
from internal EU mobility. The World Economy, 41(1), 29-58.

Migali, S., \& Scipioni, M. (2018). A global analysis of intentions to migrate. Rome: European Commission.

Mo, P. H. (2001). Corruption and economic growth. Journal of Comparative Economics, 29(1), 66-79.

Munshi, K., \& Rosenzweig, M. (2016). Networks and misallocation: Insurance, migration, and the ruralurban wage gap. American Economic Review, 106(1), 46-98.

Neumann, K., \& Hermans, F. (2017). What drives human migration in Sahelian countries? A meta-analysis. Population, Space and Place, 23(1), 1-16.

North, D. C. (1991). Institutions. Journal of Economic Perspectives, 5(1), 97-112.

OECD. (2019). What is the profile of internationally mobile students? Paris: OECD Publishing.

Palloni, A., Massey, D. S., Ceballos, M., Espinosa, K., \& Spittel, M. (2001). Social capital and international migration: A test using information on family networks. American Journal of Sociology, 106(5), 1262-1298.

Plopeanu, A., Homocianu, D., Mihaila, A. A., Crisan, L. E., Bodea, G., Bratu, R.-D., \& Airinei, D. (2018). Exploring the influence of personal motivations, beliefs and attitudes on students' post-graduation migration intentions: Evidence from three major Romanian universities. Applied Science, 8(11), 1-22.

Poprawe, M. (2015). On the relationship between corruption and migration: Empirical evidence from a gravity model of migration. Public Choice, 163(4), 337-354.

Population Council. (2016). The ILO on young people's desire to migrate. Population and Development Review, 42(4), 731-733.

Rosenzweig, M. (2006). Global wage differences and international student flows. In S. M. Collins \& C. Graham (Eds.), Brookings trade forum 2006: Global labor markets (pp 57-96). Washington, DC: Brookings International Press.

Sanny, J., Logan, C., \& Gyimah-Boadi, E. (2019). In search of opportunity: Young and educated Africans most likely to consider moving abroad (Dispatch No. 288): Accra: Afrobarometer.

Sen, K., Te Velde, D. W., Wiggins, S., \& Cali, M. (2006). Institutions and pro-poor growth: Towards a framework for quantitative analysis. Oxford: IPPG.

Terrier, E. (2009). Les migrations internationales pour études: Facteurs de mobilité et inégalité Nord-Sud [International migration for study: Mobility factors and North-South inequality]. L'Information Géographique, 73(4), 69-75.

Tilly, C. (2007). Trust networks in transnational migration. Sociological Forum, 22(1), 3-24.

United Nations. (2012). Toolkit on international migration. New York, NY: Department of Economic and Social Affair. Retrieved from https://www.un. org/en/development/desa/population/migration/ publications/others/docs/toolkit_DESA_ June\%202012.pdf

Vaal, A., \& Ebben, W. (2009). Institutions and the relation between corruption and economic growth. Review of Development Economics, 15(1), 108-123.

Van Bouwel, L. (2010). Does university quality drive international student flows? (Discussion Paper No. DP7657). Leuven: CEPR.

Waters, J. (2006). Geographies of cultural capital: Education, international migration and family strategies between Hong Kong and Canada. Transactions of the Institute of British Geographers, 31(2), 179-192.

Yue, Y. (2013). The determinants of international students inward mobility to China. Journal of National Academy, 15(18), 71-77.

Zhang, L., \& Zhang, L. (2014). An investigation and analysis on the motivation of the international students from Africa to study in China: A case study of China University of Geosciences (Wuhan). Survey of Education, 3(4), 39-42.

Zhao, L., Yuan, R., \& Wei, H. (2019). Cultural factors and study destinations of international students. China and World Economy, 27(6), 26-49.

\section{About the Author}

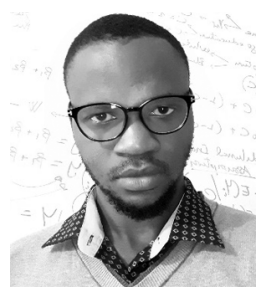

Gildas Kadoukpè Magbondé holds an MA in Applied Macroeconomics, an MA in International and Development Economics, and is a PhD Student in the Doctoral School of Human and Social Sciences at Gaston Berger University, Senegal. He is interested in development issues such as student migration, tax evasion, poverty, inequality and impact evaluation. His doctoral research focuses on foreign capital, institutions, structural transformation and economic growth in developing countries. 